\section{EMPLOYEE PARTICIPATION UNDER THE CROSS-BORDER MERGERS DIRECTIVE}

Directive 2005/56/EC of October 26, 2005 on CrossBorder Mergers of limited liability companies (OJ 2005 L310/1) contains a number of detailed provisions, some of which involve interpretative difficulties. The conclusion of this Directive was significantly delayed by the difficulty of reaching an agreement between Member States on the question of employee participation. Eventually, the rules which have been adopted concerning this matter are similar to those which are contained in the Employees' Involvement Directive (2001/86, OJ2005 L254/64) which accompanies the European Company statute.

The recent Directive does not contain a definition of employee participation, but refers to that contained in Article 2(k) of the 2001 Directive. According to Article 16(1) of the Directive, the company resulting from the merger is primarily subject to existing rules of national law where its registered office is situated. If national law contains no rules governing participation, there will be no such participation unless one of the exceptions contained in Article 16(2) applies, when such participation will be governed by rules similar to those contained in the Employees' Involvement Directive (EID), where one of the three relevant conditions set out below is fulfilled.

These are (a) where at least one of the merging companies has an employee participation system and has more than 500 employees; (b) where national law does not permit the same level of employee participation as operated in the relevant merging companies; and (c) where such law does not provide for the same level of protection for employees establishments of the company in other Member States as the relevant Member State where the reading company's registered office is situated. The above rules give rise to certain interpretative difficulties; Article 16(2)(c) should have a significant effect on German law.

The Cross Borders Mergers Directive makes use of the negotiation procedure employed for the European company. It makes reference to Article 12 of the European Company statute, which provides that a European company may only be registered if the procedure set out in the Directive is adhered to. The first stage of the relevant procedure consists of negotiations between the management organs of the participating companies and the special negotiation body, which consists of representatives of the participating companies and concerned subsidiaries and establishments. Such negotiation may take some time, but the management of the merging companies are permitted to apply the standard rules on employee participation set out in Part 3(b) of the Annex to the Employee Involvement Directive directly without such negotiation by Article 16(4)(a) of the Cross Border Mergers Directive.

\section{Articles}

Age discrimination: the new Regulations

The expanding frontiers of international law in the fight against corruption

Global business and human rights

News

\section{Articles (cont'd)}

Terrorism, pre-emptive self defence and state interests: what challenges for contemporary international legal order?

Antipathy to art in a recalcitrant court

Furthermore, Article 16(4)(b) allows the special negotiating body, by a qualified majority, not to open negotiations or terminate them, and rely on the rules in participation in the Member State of the resulting company's registered office. This may possibly occur quite frequently in practice.

The negotiation process may be used to increase or decrease participation rights. This is not possible in the case of the standard rules, which give employees of the resulting company, its subsidiaries and establishments participation rights equal to the highest proportion in the participating companies. The standard rules are applicable when the special negotiating body and the management so agree (Art 7(1)(a) of the EID); and when no agreement has been reached when the deadline for negotiations has expired (Art 7(b) of the EID); and when the parties agree on their direct application without prior negotiation (Art 16(4)(a) of the Cross Border Mergers Directive).

The rules in the new Directive concerning negotiations may sometimes have the effect of causing considerable expense to the participating companies. However, the Directive does manage to compromise between the different systems of participation in the relevant Member States, and does not appear likely to result in any significant increase in employee participation in companies in the European Economic Area. It also remains doubtful whether much use will be made of the mechanisms provided for in the Cross Border Mergers Directive in practice: agreed takeovers may often prove a more simple and satisfactory alternative. Some continental companies may, however, find the cross border merger procedure more attractive in certain situations.

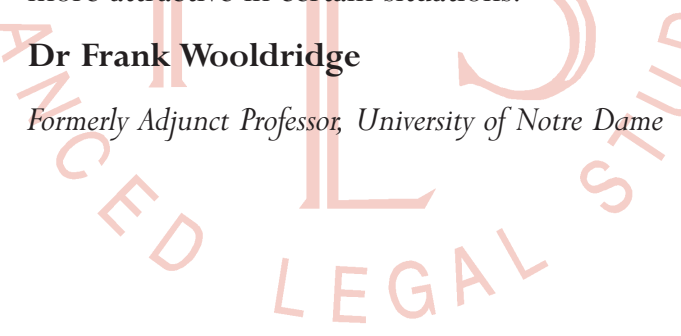

